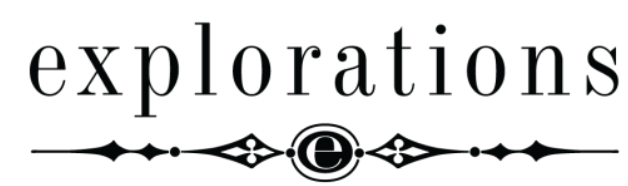

Explorations: A Journal of Language and Literature

\title{
Ekwiwalencja w przekładzie Miszny na język polski [Equivalence in the Polish Translation of the Mishnah]
}

DOI: 10.25167/EXP13.19.7.7

\section{Roman Marcinkowski (University of Warsaw)}

ORCID: 0000-0001-9646-1191

\begin{abstract}
When following the principle of translation theory, i.e. the reflection on equivalence and the process of translation, the author of the paper would like to make use of his own experience in translating literary texts of Judaism and, in particular, to refer to the first Polish translation of the Mishnah, on which he has been working for several years now. The Mishnah, which has been known in oral tradition since the 3rd century B.C. and which was written down around the year 200 A.D., forms the basis for the Talmud and is the essence of Rabbinic Judaism. The work points out how foreign views and thoughts, which are embedded in original Hebrew language structures, are being introduced into the Polish language; how the Polish language into which the translation is made determines and influences a specific type of transformation. It is not without significance that we are dealing with the first Polish translation of the Mishnah, which happens to more importantly be the Holy Book of Judaism recorded in ancient times. The author of the paper is going to determine a kind of analogy between the original (source) language of the Hebrew text and the (target) language of the text of Polish translation.
\end{abstract}

Key words: translation theory, Rabbinic Literature, Talmud

Ekwiwalencja, według wielu znawców teorii przekładu, stanowi podstawowe kryterium jego jakości. Mówiąc jednak o jakości przekładu mamy zwykle na myśli różne rodzaje ekwiwalencji lub jej brak. Jak to jest w przypadku tłumaczenia Miszny? Czy można mówić o ekwiwalencji w przekładzie Miszny? Autor artykułu próbuje określić rodzaje ekwiwalencji odnoszącej się do pierwszego przekładu Miszny na język polski.

W ciągu ostatnich kilkudziesięciu lat powstało wiele teorii na temat pojmowania ekwiwalencji w przekładzie. Mimo toczących się sporów na jej temat, dotyczących także definicji, można niezaprzeczalnie stwierdzić, że w najszerszym rozumieniu jest to rodzaj analogii między tekstem źródłowym a tekstem docelowym. Gdy obydwa teksty przekazują takie samo znaczenie, mówi się, że zachodzi między nimi ekwiwalencja. 
Francuscy uczeni Jean-Paul Vinay i Jean Darbelnet pojmowali ekwiwalencję jako procedurę odtworzenia takiej samej sytuacji, jak w oryginale, przy użyciu całkowicie innego sformułowania (Vinay and Darbelnet 1995, 342). Ta procedura, użyta w procesie tłumaczenia, może pozwolić tekstowi źródłowemu na wpłynięcie na styl tekstu docelowego $^{1}$. Według nich, ,potrzeba tworzenia ekwiwalencji wynika $\mathrm{z}$ sytuacji i w sytuacji językowej języka źródłowego tłumacz powinien szukać rozwiązania” (Vinay and Darbelnet 1995, 255).

Teoretycy przekładu zdefiniowali go i opisali na różne sposoby cały jego proces, wyróżnili też elementy składowe. W kontekście thumaczenia tekstu jest to zastąpienie (replacement) materiału tekstowego jednego języka (źródłowego) odpowiadającym mu materiałem innego języka (docelowego) na różnych poziomach (gramatycznym, leksykalnym). W ten sposób zdefiniował przekład Catford (1965, 20-25), który rozróżnił przekład wolny (free), dosłowny (literal) i słowo w słowo (word-for-word) ${ }^{2}$.

Vinay i Darbelnet $(1958 / 200,84)$ wyróżnili dwie metody przekładu: przekład bezpośredni (direct translation) i pośredni (oblique translation). Przekład bezpośredni przypomina - ich zdaniem - cytowanie słowo w słowo oryginalną wiadomość do języka docelowego włączając $w$ to zapożyczenia, kalki językowe i tłumaczenie dosłowne. W przekładzie pośrednim tłumacz interpretuje, tzn. rozszerza lub zawęża oryginalny tekst, co obejmuje transpozycję, modulację, ekwiwalencję i adaptację. Te strategie ${ }^{3}$ odbywają się na trzech poziomach języka: a) słownictwa, b) struktur gramatycznych i c) wiadomości, która stanowi wyższy element tekstu obejmujący oprócz zdań czy rozdziałów konkretne wyrażenia sytuacyjne niosące szersze znaczenie. Użycie wymienionych metod ma umożliwić sformułowanie tekstu docelowego w taki sposób, aby wywoływał on podobne reakcje u czytelnika docelowego, co tekst oryginalny $\mathrm{u}$ czytelnika wyjściowego.

Inaczej mówiąc ekwiwalencja w przekładzie wiąże się ściśle $\mathrm{z}$ podziałem na tłumaczenie dosłowne, gdzie najogólniej to ujmując poszczególne słowa tekstu źródłowego odpowiadają wyrazom w tekście docelowym, i wolne, które skupia się na uchwyceniu sensu większych niż jeden wyraz fragmentów tekstu, grup leksemów tworzących pojedyncze elementy myślowe (Waliński 2015, 55).

To oznacza, że ekwiwalencja bliższa jest tłumaczeniu bezpośredniemu, a w przekładzie pośrednim nie wyróżnia się zbytnio od innych jego cech. Jeśli ekwiwalencję w przekładzie rozumieć jako zgodność tekstu źródłowego z tekstem docelowym, to niezgodność obu tekstów oznacza brak ekwiwalencji. Na niezgodność tekstu źródłowego z tekstem docelowym zwracało uwagę wielu uczonych.

Miszna, ostatecznie spisana po hebrajsku pod koniec II wieku n.e., stanowi istotę judaizmu rabinicznego oraz pierwszą i podstawową część tzw. Tory Ustnej. Judaizm uznaje objawienie Tory w dwu formach: spisanej i ustnej. Pierwsza nosi nazwę Tora szebichtaw - Tora Spisana, a druga Tora szebeal-pe - Tora Ustna. Zgodnie z wierzeniami

\footnotetext{
${ }^{1}$ Ich zdaniem, ekwiwalencja jest idealną metodą do tłumaczenia przysłów, idiomów, stereotypów myślowych, wyrażeń rzeczownikowych i przymiotnikowych oraz wyrazów dźwiękonaśladowczych.

2 Np. ros. Бог с ними! oddaje po angielsku:

a) God with them! (słowo w słowo)

b) God is with them! (przekład dosłowny)

c) Never mind about them! (przekład wolny).

${ }^{3}$ Więcej na temat strategii w przekładzie: Piotrowska 2008, 224.
} 
judaizmu obie objawił Bóg Mojżeszowi na Synaju. Autor artykułu zainicjował pierwszy polski przekład Miszny ${ }^{4}$, tworzącej razem z Gemarą główne części Talmudu.

Język Miszny w literaturze przedmiotu postrzegany jest jako część ogólniejszego zjawiska językowego nazywanego ,językiem Mędrców” (hebr. leszon chachamim) ${ }^{5}$. Badania dowodzą, że po hebrajsku w Palestynie mówiono prawie do końca II wieku n.e., o czym świadczy żywy język tannaitów ${ }^{6}$ z różnych części Palestyny. Do 200 roku p.n.e., tzn. przed okresem hasmonejskim, pisano po hebrajsku wyłącznie w języku biblijnym. „Język Mędrców” pojawił się jako język literacki dopiero pod koniec I wieku n.e. (Bar-Asher 1995, 3).

Eugene A. Nida w swych badaniach nad teorią przekładu wskazał, że obejmuje on trzy stany: analizę, przeniesienie i odwzorowanie, nazywane też odkodowaniem. Wspomniana analiza to - jego zdaniem - zakodowanie lub zredukowanie wiadomości języka źródłowego do jego podstawowych struktur. Przeniesienie polega na przekształceniu podstawowych struktur języka źródłowego na odpowiadające im struktury języka docelowego. Odwzorowanie zaś, zwane także odkodowaniem, sprowadza się do ponownego złożenia wiadomości w zrozumiałej, naturalnej formie języka docelowego (Nida 1961, Price 2007, 3). W przypadku tłumaczenia Miszny konieczny jest czwarty element, którym jest komentarz ${ }^{7}$ do przekładu. Wszystkie tłumaczenia Miszny są przekładami komentowanymi ${ }^{8} \mathrm{z}$ wyjątkiem pracy Neusnera (1988). Również sam Nida wspomina o konieczności tworzenia przypisów dla lepszego zrozumienia przekładu (Nida 1964, 159).

Wspomniany wyżej Eugene A. Nida, skupiający swoje badania na przekładzie Biblii, wyróżnił ekwiwalencję dynamiczną, zwaną też funkcjonalną i ekwiwalencję formalną. Okazało się, że te kategorie można zastosować do każdego typu thumaczenia. Ekwiwalencja dynamiczna (funkcjonalna) przekazuje główną myśl wyrażoną w tekście źródłowym. Jeśli jest to konieczne, cel ten osiągany jest kosztem dosłowności, oryginalności sememu, a także kolejności wyrazów w zdaniu, formy gramatycznej tekstu

${ }^{4}$ Do tej pory ukazały się trzy z sześciu działów Miszny zwanych dosłownie porządkami:

1. Miszna: Zeraim (Nasiona) pod redakcją naukową Romana Marcinkowskiego, Wydawnictwo DiG, Warszawa 2013, ss. 327.

2. Miszna: Moed (Święto) pod redakcją naukową Romana Marcinkowskiego, Wydawnictwo DiG, Warszawa 2014, ss. 299.

3. Miszna: Naszim (Kobiety), Wstęp, przekład z języka hebrajskiego i opracowanie: Roman Marcinkowski, Wydawnictwo DiG - Edition La Rama, Warszawa-Bellerive-sur-Allier 2016, ss. 455.

5 Język misznaicki jest nazywany także ,językiem Mędrców”. To określenie stosuje się do dialektu języka hebrajskiego używanego przez Żydów w I-V w. n.e. Język Mędrców dzieli się zwykle na dwie podgrupy: a) język, w którym spisano Misznę i Toseftę i b) język, w którym spisano fragmenty Talmudu Babilońskiego i Talmudu Jerozolimskiego, a także midrasze halachiczne i agady. Mędrcy talmudyczni wyraźnie go odróżniali od języka Biblii hebrajskiej, o czym świadczy zapis talmudyczny: לשון תורה לעצמה ולשון חכמים לעצמה leszon Tora leacmah uleszon chachamim leacmah, co można by przetłumaczyć jako: „Język Tory i język Mędrców istnieją niezależnie" (Talmud Babiloński, Awoda Zara 58b).

${ }^{6}$ Tak określa się redaktorów Miszny.

${ }^{7}$ Istnieją komentarze do Miszny bez przekładu tekstu. Do najważniejszych współcześnie zalicza się: Chanoch Albeck, ששה סדרי משנה Szisza Sidre Miszna (hebr. Sześć Porządków Miszny), Jeruszalajim (Jerozolima) 2008 (Wyd. I Jeruszalajim 1953) oraz Pinchas Kehati, משניות מבוארות Misznajot mewoarot, Jeruszalajim 5764 (2003). ${ }^{8}$ Do najważniejszych należą: Herbert Danby, The Mishnah, Translated from Hebrew with Introduction and Brief Explanatory Notes, Peabody, Massachusetts 2016 (Wyd. I Oxford 1933) oraz przekład komentarza P. Kehatiego z thumaczeniem tekstu Miszny na język angielski: Pinchas Kehati, The Mishnah, A New Translation With a Commentary, Translated by Rafael Fisch, Jerusalem 1994. 
źródłowego itd. Ekwiwalencja formalna (odwzorowana w tłumaczeniu dosłownym) stara się traktować tekst bardziej dosłownie lub nawet „słowo w słowo”. Niekiedy ten rodzaj ekwiwalencji jest osiągany kosztem naturalności języka docelowego.

W moim przekładzie Miszny na język polski znaleźć można obie formy ekwiwalencji. Myślę, że dominującą jest ekwiwalencja formalna, starająca się traktować tekst dosłownie, jednak nie nazbyt dosłownie, żeby nie zatracić naturalności języka docelowego, co jest zjawiskiem powszechnym w przekładach literatury rabinicznej na język polski. Nie zawsze jednak da się zachować w przekładzie ekwiwalencję formalną. Jednym $\mathrm{z}$ powodów dla tego zjawiska może być sytuacja, w której język hebrajski zawiera słowo opisujące pojęcie nieposiadające bezpośredniego odpowiednika w języku polskim. W takiej sytuacji koniecznością staje się zastosowanie przekładu dynamicznego lub utworzenie w języku polskim neologizmu reprezentującego dane pojęcie (czasami poprzez zapożyczenie słowa z języka źródłowego).

Przykład utworzonego neologizmu w przekładzie Miszny na język polski:

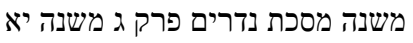

Konam szeeini nehene liwnei Noach - [Jeśli ktoś powiedział:] „Konam, że nie będę miał korzyści od Noachitów"9. (Ned 3,11)

Szkocki językoznawca John Catford wyróżnił w badaniach na tekstem ekwiwalencję tekstualną i korespondencję formalną. Jego zdaniem ekwiwalencja tekstualna zachodzi, gdy dany tekst lub jego fragment w języku docelowym jest uważany za ekwiwalentny w stosunku do tego samego tekstu lub jego fragmentu w języku źródłowym. Korespondencja formalna zaś ma miejsce, gdy dana kategoria gramatyczna w języku docelowym zajmuje mniej więcej to samo miejsce, co korespondująca kategoria w języku źródłowym. Zgodność formalna jest często niemożliwa do zachowania, szczególnie gdy obydwa języki są bardzo od siebie odległe.

Podobną funkcję do angielskiego przedimka określonego ,the” pełni w języku hebrajskim przedimek określający „ha” (nazywany determinatywem, przedimkiem lub rodzajnikiem, Tyloch 1985, 94) ${ }^{10}$. Zgodnie z założeniami Catforda obecność lub brak tego przedimka w tekście oryginalnym należałoby uwzględniać w przekładzie

\footnotetext{
9 Hebr. bnei Noach - dosł. „synowie Noego”, tym wyrażeniem określa się w Talmudzie ludzi różnych narodowości z wyjątkiem Izraela. Od tego złożenia bnei Noach (synowie Nowego) utworzyłem wyraz Noachici (od hebr. Noach - Noe), który zastosowałem po raz pierwszy w swojej książce: R. Marcinkowski, Paradygmaty religijności $w$ judaizmie rabinicznym. Miszna $i$ inne teksty talmudyczne o szabacie, święcie, pótświęcie $i$ powszedniości, Kraków 2004, szczególnie strony 176-193. Obcych nazywano: ben Noach - „syn Noego”, „,nochri” - „cudzoziemiec”, goj - „,naród (obcy)” oraz ger lub ger toszaw - „obcy mieszkający pośród Izraelitów".

${ }^{10}$ Hebr. he hajedi' $a$, ang. the definite article, nazywane jest zwykle determinatywem, przedimkiem lub rodzajnikiem. Tyloch $(1985,94)$ używa nazwy ,zaimek określający”. Marcinkowski $(2016,25)$ stosuje nazwę „przedimek określający”, ponieważ hebrajskie he hajedi 'a nie zastępuje imienia, czyli nie pełni funkcji zaimka. Nie jest też rodzajnikiem, gdyż nie określa rodzaju. Nie wskazuje także liczby. Występuje najczęściej przed imieniem, określając je, stąd nazwa. W języku hebrajskim kategoria imienia obejmuje rzeczowniki, przymiotniki oraz liczebniki. Przedimek określajacy „ha” może też występować przed nieosobowymi formami czasownika: imiesłowem lub bezokolicznikiem. Nowicki $(1978,35)$ nazywa go „określaczem”. Po niemiecku nazywany jest zwykle: „der Artikel” (Simon 1977, 20), „,der bestimmte Artikel” (Steuernagel 1962, 42) lub Determinationspartikel (Körner1986, 69).
} 
odpowiednio użytym szykiem zdania. Np. misznaickie בשר שנמצא בעזרה Basar szenimca baazara - dosł. Mięso, które zostało znalezione na dziedzińcu światynnym (Szek 7,3) należałoby zgodnie z teorią Catforda przetłumaczyć z uwzględnieniem pierwszeństwa terminu określonego בעזרה baazara- ,na dziedzińcu świątynnym” przed nieokreślonym בשר w przekładzie Miszny: [Jeśli] na dziedzińcu światynnym zostało znalezione [jakieś] mięso... Jednak Miszna rządzi się swoimi prawami wypracowanymi przez lata przekazu ustnego i teoria Catforda nie ma tu zastosowania. Porównajmy przekłady na język angielski:

If flesh was found in the Temple Court... (Danby 2016, 160)

Meat that was found in the Temple courtyard... (Kehati 1994, 79)

Meat which is found in the courtyard... (Neusner 1988, 262)

Kל ששה חדשים השלוחין יוצאין Korespondencja formalna zachodzi np. między hebrajskim Al szisza chodaszim haszluchim jocein i polskim $Z$ powodu sześciu miesięcy postańcy wychodza (Rosz Hasz 1,3).

Porównajmy przekład angielski:

Because of six New Moons do messengers go forth (Danby 2016, s. 188)

On six months the messengers go forth (Kehati 1994, s. 10)

On the occasion of six new moons messengers go forth (Neusner 1988, 300)

Podobnie też mamy do czynienia z korespondencją formalną w zdaniu źródłowym אב Aw uwno szerau et hachodesz, jelechu i jego polskim przekładzie [Jeśli] ojciec i jego syn zobaczyli [nowy] księżyc, to niech pójda [razem]. (Rosz Hasz 1,7)

Porównajmy przekład angielski:

If a father and his son saw the new moon they may [both] go. (Danby 2016, 189)

If a father and his son saw the New Moon, they go. (Kehati 1994, 15)

A father and his son who saw the new moon should go. (Neusner 1988, 300)

Kolejny przykład korespondencji formalnej między fragmentem tekstu źródłowego i docelowego:

$$
\begin{aligned}
& \text { משנה מסכת ראש השנה פרק א משנה ח }
\end{aligned}
$$

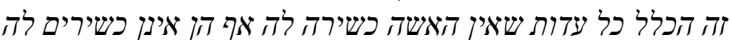

Ze haklal: Kol edut szeein haisza kszera lah, af hen einan kszerim lah. - Taka jest zasada: Każde świadectwo, którego nie jest zdatna [złożyć] kobieta, również oni nie sq do niego zdatni. (Rosz Hasz 1,8)

Porównaj przekład angielski:

This is the general rule: any evidence that a woman is not eligible to bring, these are not eligible to bring. (Danby 2016, 189) 
This is the general rule: any testimony which the woman is ineligible to give, these are also ineligible to give. (Kehati 1994, 17)

This is the governing principle: Any evidence which a woman is not valid [to offer], also they are not valid [to offer]. (Neusner 1988, 301)

Drugi człon charakterystycznego dla języka hebrajskiego złożenia dwu imion (najczęściej rzeczowników) nazywanego status constructus, jest zwykle tłumaczony na języki docelowe zgodnie z jego właściwą funkcją, czyli w dopełniaczu, ale możliwe jest również użycie formy atrybutywnej.

W przekładzie na język polski ta konstrukcja również bywa zachowana ekwiwalentnie, np.:

aw hatum'a - dosł. „ojciec nieczystości” (drugi stopień nieczystości), tiglachat mecora - dosł. „strzyżenie trędowatego”, tiglachat nazir - dosł. „strzyżenie nazarejczyka”, Torat Kohanim - Prawo kapłanów, techum szabat - „zasięg szabatu”), Jom Hanef - Dzień Kołysania, Erec Israel - dosł. „Kraj Izraela”, Palestyna ${ }^{11}$.

W przekładzie na język polski zwykle unika się konstrukcji dopełniaczowej i tam, gdzie jest to możliwe, drugi człon złożenia status constructus tłumaczy się przymiotnikowo, np.: nezir olam - dosł. „wieczny nazarejczyk”, nezir Szimszon - dosł. „nazirejczyk Samsonowy”. Podobnie hebr. nezir olam (Naz 1,2) thumaczone jest na angielski jako „permanent nazir”, (Kehati 1994, 3), „lifelong Nazirite” (Danby 2016, 281), „a life-long Nazirite” (Neusner 1988, 431), a złożenie נזיר שמשון nezir Szimszon (Naz 1,2) oddano w języku angielskim jako „Samsonian nazir” (Kehati 1994, 3), ,a Nazirite the like of Samson” (Danby 2016, 281), ,a Nazirite in the status of Samson” (Neusner 1988, 431).

Język Miszny zawiera wiele wyrazów lub zwrotów zwykle dwuwyrazowych, których nie da się przetłumaczyć, a jeśli da się je przełożyć, to ich przekład zwykle zawęża znaczenie oryginalnego wyrażenia. Są wśród nich i takie, które można przetłumaczyć, ale oryginalne hebrajskie nazewnictwo tak się zadomowiło w kulturze żydowskiej w diasporze, że zwykle się tego nie tłumaczy.

Do pierwszej grupy należą m.in.: chala ${ }^{12}$, chaluca $^{13}$, chazaka $^{14}$, eruw $^{15}$, jewama ${ }^{16}$, karmelit $^{17}$, kilajim $^{18}$, meduma ${ }^{19}$, pea $^{20}$, pigul ${ }^{21}$, prozbul ${ }^{22}$, szemita ${ }^{23}$ oraz cet

\footnotetext{
${ }^{11}$ Tu warto dodać, że nazwa oryginalna współczesnego izraelskiego państwa brzmi מדינת ישראל, , co poprawnie po polsku należy oddać jako „Państwo Izraela”, jak zachowują to w przekładzie niektóre języki docelowe, np.

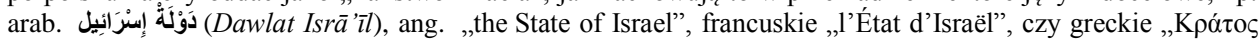

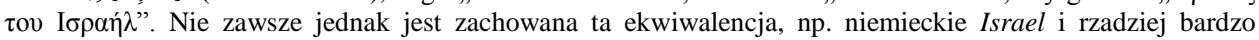
oficjalnie Staat Israel, podobnie do rosyjskiego Изра́иль i rzadziej używanego Госуда́рство Изра́иль.

${ }^{12}$ Chala — dar ofiarny z ciasta, niewielka ilość ciasta wydzielana dla kapłana. Zgodnie z halacha ustaloną na podstawie opinii mędrców minimalna wielkość ciasta, która wypełnia obowiązek chala to pięć ćwierci miary kaw, czyli pięć log (ok. 2,5 litra).

${ }^{13}$ Chaluca - wdowa po bezdzietnie zmarłym, która dopełnia obrządku chalicy, zdejmując but z nogi brata jej zmarłego męża, tym samym kobieta zdejmowała ze szwagra obowiązek małżeństwa lewirackiego i sama uwalniała się spod tego prawa.

${ }^{14}$ Chazaka - przejęcie prawa własności na skutek posiadania obiektu lub zasiedzenia nieruchomości przez określony prawnie okres.

${ }^{15}$ Eruw - hebr. „zmieszanie, pomieszanie”, to „utworzenie symbolicznej łączności miejsca lub ciągłości wykonywania pewnej czynności”, oznacza symboliczne akty i zarazem sposób na uchylenie zakazu
} 
hakochawim $^{24}$, jamim towim ${ }^{25}$, majim riszonim ${ }^{26}$, majim acharonim $^{27}$. Do drugiej kategorii można zaliczyć następujące wyrazy: cedaka ${ }^{28}$, hawdala ${ }^{29}$, hefker ${ }^{30}$, hekdesz ${ }^{31}$, mamzer $^{32}$, mawoj ${ }^{33}$.

Oprócz hermetycznej i często nieprzetłumaczalnej terminologii inną przyczyną niezachowania w przekładzie Miszny ekwiwalencji formalnej były charakterystyczne dla tego języka skróty myślowe, które służyły niegdyś łatwiejszemu zapamiętywaniu tekstu, a dzisiaj w dużym stopniu utrudniają jego zrozumienie, zwłaszcza dla początkującego badacza i nastręczają wiele trudności przy jego interpretacji, np.: „ogolenie czystości” - tiglachat hatohora תגלחת הטהרה lub „ogolenie nieczystości” tiglachat hatum'a תגלחת הטומאה.

wykonywania zabronionych w szabat i święta czynności. Ten sposób na uchylenie pewnych zakazów stosuje się głównie do działań, których spełnienie jest konieczne dla właściwego wypełnienia

szabatu lub święta. Eruw oznacza włączenie prac zabronionych w sferę dozwolonych. Ważniejsze formy eruwu: 1) eruw chacerot (dosł. „zmieszanie dziedzińców”) — zezwolenie na przenoszenie przedmiotów na terenie większym niż jedna domena prywatna, wspólnym dla wielu osób, 2) eruw tawszilin (,zmieszanie potraw”) zezwolenie na gotowanie, przyrządzanie posiłku na szabat w święto, które wypada w piątek, 3) eruw techumim — (,zmieszanie obszarów”) — zezwolenie na wyjście poza zasięg szabatu (techum szabat).

${ }^{16}$ Jewama - owdowiała bratowa po bezdzietnie zmarłym bracie, która podlega prawu lewiratu względem szwagra lub szwagrów.

${ }^{17}$ Karmelit - morze lub dolina, miejsce na odludziu, gdzie prawie nikt nie chodzi lub obszar o wymiarach cztery na cztery tefach otoczony murami niższymi od dziesięciu tefach, ale wyższymi niż trzy tefach; w przestrzeganiu szabatu domena neutralna, która nie jest ani domeną prywatną ani publiczną.

${ }^{18}$ Kilajim - zakaz mieszania dwóch gatunków roślin, zwierząt i odzieży.

${ }^{19}$ Meduma - mieszanka produktu dozwolonego i zabronionego.

${ }^{20}$ Pea - skraj pola (zwykle zboża) lub skraj ogrodu, z których nie zbiera się plonu z przeznaczeniem dla biednych lub przybyszów.

${ }^{21}$ Pigul - mięso ofiary, które urzędujący kapłan przeznaczył do spożycia w niewłaściwym miejscu lub czasie.

${ }^{22}$ Prozbul lub prozbol, ewentualnie pruzbol, na podstawie Pwt 15,2 wszelkie długi związane z pożyczkami znosi rok szabatowy. Aby uniknąć sytuacji, w której nie chciano pożyczać w obliczu zbliżającego się roku szabatowego w obawie o utratę pożyczonych pieniędzy, Hillel ustanowił regułę prozbulu, tzn. deklaracji sądowej wierzyciela podpisanej przez świadków o uchyleniu warunków roku szabatowego.

${ }^{23}$ Szemita — „darowanie” oznacza rok darowania długów, czyli rok szabatowy (szewiit). W szerszym znaczeniu obejmuje cykl siedmioletni kończący się rokiem szabatowym.

${ }^{24}$ Cet hakochawim — ,pojawienie się gwiazd” na niebie oznaczające wieczór i zarazem początek nowej doby w judaizmie.

${ }^{25}$ Jamim towim - dosł. „dobre dni”, termin stosowany na określenie pełnych dni świątecznych, zwykle oznacza pierwszy i ostatni dzień święta, dni pomiędzy nimi są traktowane jak powszednie czasu świątecznego, czyli półświęto (chol hamoed)

${ }^{26}$ Majim riszonim - dosł. ,pierwsza woda”, woda do mycia rąk przed łamaniem chleba.

${ }^{27}$ Majim acharonim — dosł. „ostatnia woda”, woda służąca do mycia rąk po jedzeniu.

${ }^{28}$ Cedaka - jałmużna. Termin cedaka zmienił znaczenie ze „sprawiedliwość” w biblijnym hebrajskim na ,jałmużna” w języku Miszny.

${ }_{29}$ Hawdala - hebr. „oddzielenie”, „odłączenie”, błogosławieństwo na zakończenie szabatu lub święta oddzielające czas świąteczny od powszedniego.

30 Hefker (w dialekcie palestyńskim) lub hewker (w dialekcie jerozolimskim) — mienie bezpańskie, wyrzeczenie się prawa własności jakiegoś mienia i udostępnienie go wszystkim.

${ }^{31}$ Hekdesz - to, co poświęcone dla Świątyni.

${ }^{32}$ Mamzer (r.m.), mamzeret (r.ż.) — dziecko z nieprawego łoża, cudzołóstwa lub kazirodztwa. Zakazani byli w związkach małżeńskich dla ogółu Izraela.

${ }^{33}$ Mawoj — „uliczka”, ,zaułek” oznacza w kontekście przestrzegania szabatu wspólne wejście. Rozróżnia się dwa rodzaje mawoj: a) mawoj zamknięte - wąska uliczka lub alejka otoczona z trzech stron działkami, b) mawoj mefulasz — „otwarte”, ,przejściowe”, ogrodzone dwoma równoległymi murami i otwarte na końcu.

34 Powyższe skróty myślowe zostaną wyjaśnione na końcu artykułu wraz z przykładem wskazującym konieczność komentarza dla właściwego zrozumienia tekstu Miszny. 
O dylematach z rozumieniem wyrazów i właściwą ich interpretacją informuje sama Miszna. Problem z ustaleniem popularnego rozumienia terminów omawia w ósmym rozdziale traktat Miszny Nedarim. W pierwszej lekcji tego rozdziału tannaici zwracają szczególną uwage na wyrażenia określające ograniczenia czasowe w ich popularnym znaczeniu:

[Jeśli mężczyzna powiedział:] „Konam, jeśli spróbuję wina dzisiaj”, 35 to jest mu zabronione tylko do zmierzchu. ${ }^{36}$ [Jeśli powiedział:] „w tym tygodniu", 37 to jest mu zabronione do [końca] tygodnia łącznie z nadchodzącym szabatem, ${ }^{38}$ który liczy się z minionym tygodniem. [Jeśli powiedział:] „w tym miesiącu”, ${ }^{39}$ to jest mu zabronione do [końca] miesiąca ${ }^{40} \mathrm{i}$ przez pierwszy dzień ${ }^{41}$ następnego ${ }^{42}$ miesiąca. [Jeśli powiedział:] ,w tym roku", ${ }^{43}$ to jest mu zabronione do [końca] tego roku i w pierwszy dzień przyszłego roku. ${ }^{44}$ [Jeśli powiedział:] ,przez to siedmiolecie,"45 to jest mu zabronione do końca siedmioletniego ${ }^{46}$ [cyklu szemita] i przez rok szabatowy, który liczy się łącznie z minionymi latami [w cyklu szemita. Jeśli jednak] powiedział: ,jeden dzień", 47 ,jeden tydzień", 48 ,jeden miesiąc", ${ }^{49}$, ,jeden rok", 50 lub ,jedno siedmiolecie" ${ }^{, 51}$, to jest mu zabronione od [tego] dnia do [tego samego momentu następnego] dnia ${ }^{52}$, [tygodnia, miesiąca, roku lub siedmiolecia]. (Ned 8,1)

Kolejna lekcja tego rozdziału stanowi kontynuację poprzedniej, rozwija zagadnienie określeń czasu użytych w formie ślubu, a w szczególności dotyczy określeń „aż do”, ,aż będzie” i „aż przed”. Samo ,aż” nie włącza do terminu ślubu konkretnie wskazanej pory, do której dany ślub ma trwać:

[Jeśli powiedział:] ,aż do Pesach ${ }^{, 53}$, to jest mu zabronione, aż nadejdzie ${ }^{54}$ [Pesach. Jeśli powiedział:] ,aż będzie [Pesach] ${ }^{155}$, to jest mu zabronione, aż skończy się ${ }^{56}$

\footnotetext{
${ }^{35}$ Hebr. hajom - dosł. „dzisiaj”. Mężczyzna ślubował nie pić wina, które stanowi tu tylko przykład jednego z napojów czy rodzajów pożywienia i określił czas trwania ślubu.

${ }^{36}$ Hebr. ad szetechszach - ,aż się ściemni”.

${ }^{37}$ Hebr. szabat zo - dosł. „ten szabat”, tzn. do końca tego tygodnia łącznie z szabatem, siódmym dniem tygodnia.

${ }^{38}$ Hebr. weszabat szeawra - dosł. „, i szabat, który minął”. Inna wersja tekstu wehaszabat leszeawar - dosł. „, i miniony szabat".

${ }^{39}$ Hebr. chodesz ze - dosł. „ten miesiąc”.

${ }^{40}$ Od dnia złożenia ślubu.

${ }^{41}$ Hebr. rosz chodesz - dosł. ,początek miesiąca”. Dawniej pierwszy dzień nowego miesiąca był świętem.

${ }^{42}$ Hebr. lehaba - dosł. „który nadejdzie”.

${ }^{43}$ Hebr. szana zo-dosł. „ten rok”.

${ }^{44}$ Hebr. werosz haszana leatid lawo - dosł. ,i nowy rok, który ma nadejść na przyszłość”.

${ }^{45}$ Hebr. wyrażenie szawua ze w czasach Miszny oznaczało „to siedmiolecie”, współcześnie „ten tydzień”.

${ }^{46}$ Hebr. bechol haszawua - ,przez całe siedem lat”, współcześnie rozumiane ,„przez cały tydzień”.

${ }^{47}$ Hebr. jom echad.

${ }^{48}$ Hebr. szabat achat - dosł. ,jeden szabat”

${ }^{49}$ Hebr. chodesz echad.

${ }^{50}$ Hebr. szana achat.

${ }^{51}$ Hebr. szawua echad.

${ }^{52}$ Hebr. mijom lejom - dosł. „od dnia do dnia”. Ślub obowiązuje wówczas od chwili złożenia go do tej samej godziny następnego dnia. Podobnie jest w pozostałych terminach ślubu, który liczy się od chwili rozpoczęcia do tego samego momentu np. ósmego dnia w przypadku ślubu tygodniowego.

${ }^{53}$ Hebr. ad haPesach - dosł. ,aż do Pesach”.
} 
[Pesach]. Jeśli powiedział:] „aż przed Pesach"57 - rabi Meir mówi: Jest mu zabronione, aż nadejdzie ${ }^{58}$ [Pesach]. Rabi Jose [zaś] mówi: Jest mu zabronione, aż skończy się ${ }^{59}[\text { Pesach }]^{60}$. (Ned 8,2)

W poprzedniej misznie ${ }^{61}$ wyjaśniono, że wyrażenia ad - „do” i ad szejagi'a - ,aż nadejdzie" w popularnym ich rozumieniu oznaczały trwanie ślubu do nadejścia określonego czasu czy terminu, a zwrot ad szejehe - ,aż będzie” oznaczał trwanie ślubu łącznie $z$ danym terminem, np. święta. Ta miszna to potwierdza, wskazuje jednak, że w przypadku, gdy wyznaczony czas nie jest sprecyzowany, również wyrażenie ad szejehe „aż będzie” nie włącza do okresu trwania ślubu tego wyznaczonego bliżej niesprecyzowanego czasu i oznacza tyle, co „do czasu, który nadejdzie”, a nie „do czasu, który się skończy", jak to było w poprzedniej misznie. Tym samym przestaje tu istnieć różnica $\mathrm{w}$ popularnym rozumieniu tych terminów, którą podkreślono $\mathrm{w}$ poprzedniej lekcji:

Jeśli powiedział: „do żniw”, „do winobrania” [lub] „do zbioru oliwek”, to jest [mu] zabronione tylko [do czasu], kiedy nadejdzie [ta pora]. Taka jest reguła: „Wszystko, co ma ustalony czas”, to znaczy, że jeśli mężczyzna powiedział „aż nadejdzie” i [odnosi się to do] ,wszystkiego, co ma ustalony czas”, [to jego ślub] jest wiążący do nadejścia [tej pory. Jeśli powiedział:] „aż będzie”, to [jego ślub] jest wiążący aż do zakończenia [tej pory]. A [jeśli chodzi o] wszystko, co nie ma ustalonego $\mathrm{czasu}^{62}$, to bez różnicy, czy powiedział „aż będzie”, czy powiedział „aż nadejdzie”, [jego ślub] jest wiążący tylko do nadejścia [tej pory]. (Ned 8,3)

W innym miejscu tego samego traktatu (Ned 6,8) tannaici rozważają zagadnienie produktów pochodnych od tych, które stanowiły istotę ślubu zabraniającego ich spożywania. Najpierw (Ned 6,7) wskazano, że pochodne „winogron” (hebr. anawim) i „oliwek” (hebr. zeitim) mają swoje niezależne nazwy: „wino” (jajin) i „oliwa” (szemen). Tutaj produkty pochodzące z „daktyli” (hebr. temarim) i z jesiennych winogron (hebr. sitwanijot) zawierają w swych hebrajskich nazwach ich pierwotne pochodzenie: dewasz

\footnotetext{
${ }^{54}$ Hebr. ad szejagi'a - dosł. ,aż nadejdzie”. Ale w święto już mu wolno.

${ }^{55}$ Hebr. ad szejehe - dosł. ,aż będzie”.

${ }^{56}$ Hebr. ad szejece - ,aż odejdzie”. Zakaz obowiązuje także przez całe święto.

${ }^{57}$ Hebr. ad lifne haPesach - dosł. ,aż przed Pesach”, według innej wersji ad pene haPesach - dosł. „aż do oblicza Pesach", por. Kid 64b.

${ }^{58}$ Rabi Meir rozumie to sformułowanie jako ad szejagi'a haPesach - dosł. ,aż nadejdzie Pesach”.

${ }^{59}$ Rabi Jose rozumie zwrot ad lifne haPesach - ,aż przed Pesach” jako ad szejece - „aż odejdzie” Pesach.

${ }^{60} \mathrm{Z}$ powyższego fragmentu dowiadujemy się, że ustalenie popularnego znaczenia określonych terminów lub zwrotów nie było zawsze proste, czego dowodzi przytoczony tu spór pomiędzy rabim Meirem i rabim Jose.

${ }^{61}$ Termin miszna pisane przez małe „m”, inaczej „lekcja”, oznacza najmniejszą część tego najważniejszego dzieła literatury rabinicznej, którego nazwę piszemy wielką literą.

${ }^{62}$ Terminy żniw, winobrania czy zbioru oliwek nie są tak precyzyjne jak ustalone terminy świąt, gdyż w ich przypadku z góry wiadomo, kiedy dane święto się skończy. Terminu zakończenia zbiorów ślubujący nie może precyzyjne określić, dlatego należy przyjać, że miał na myśli czas ich rozpoczęcia i tylko do tego momentu obowiązuje go złożony przez niego ślub, nawet jeśli użył sformułowania ad szejehe - ,aż będzie”, por. Albeck (2008 III 172); Kehati (2003); Kehati (1994). (Jeśli przy cytowaniu powyższych publikacji nie podano strony, to cytat odnosi się do komentowanego fragmentu Miszny, tego samego traktatu, rozdziału i lekcji, w tym miejscu, tutaj jest to Ned 8,3. W przypadku dzieła Pinchasa Kehatiego obejmuje obie wersje: hebrajską i angielską).
} 
temarim - „miód daktylowy” i chomec sitwamijot - „ocet winny” sporządzany z późnych winogron. Jeśli nazwa produktu pochodnego jest choćby w części identyczna $\mathrm{z}$ nazwą produktu głównego, to zakaz obowiązuje obydwa produkty: główny i pochodny:

Jeśli ktoś ślubował [powstrzymywać się] od daktyli, to wolno [mu spożyć] miód daktylowy ${ }^{63}$; jeśli od jesiennych winogron, to może [spożyć sporządzony z nich] ocet winny $^{64}$. Rabi Jehuda ben Betera mówi: Jeśli coś określa się nazwą ${ }^{65}$ tego, od czego pochodzi, na co ktoś ślubował, to i to pochodne jest mu zabronione. Mędrcy jednak zezwalają $^{66}$. (Ned 6,8)

W poprzedniej lekcji wspólna choćby w części nazwa produktu głównego i pochodnego była przyczyną uznania za zabroniony także tego ostatniego. Ned 6,9 w przeciwieństwie do poprzedniej miszny naucza, że ten, kto ma zabroniony ślubem jakiś konkretny produkt, może spożyć podobny, który nosił nawet tę samą nazwę, ale jest w niej zawarte uzupełnienie, dodatkowy wyraz, przez co ten produkt pochodny różni się w nazwie od zabronionego produktu głównego:

Jeśli ktoś ślubował [powstrzymywać się] od wina ${ }^{67}$, to może [napić się] wina $\mathrm{z}$ jabłek $^{68}$; jeśli od oleju ${ }^{69}$, wolno [mu spożyć] olej sezamowy ${ }^{70}$; jeśli od miodu ${ }^{71}$, to wolno [mu zjeść] miód daktylowy ${ }^{72}$; jeśli od octu ${ }^{73}$, to wolno [mu skosztować] octu winnego $\mathrm{z}$ jesiennych winogron ${ }^{74}$; jeśli od porów $^{75}$, to wolno [mu jeść] kaflotot $^{76}$; jeśli

\footnotetext{
${ }^{63}$ Ponieważ ślubujący miał na myśli podczas ślubowania tylko zasadnicze produkty, a nie ich pochodne.

${ }^{64}$ Hebr. chomec sitwanijot. Z winogron dojrzewających jesienią sporządzano ocet winny, a nie wino. Tu zakałda się, że ślubujący miał na myśli główny produkt, a nie jego pochodne mimo iż jesiennych winogron nie spożywano bezpośrednio, a służyły jedynie do sporządzania octu winnego, por. Albeck III 167; Kehati, Ned 6,8 .

${ }^{65}$ Rabi Jehuda ben Betera twierdzi, że jeśli nazwa produktu pochodnego (jak w opisanych w tej misznie przypadkach) jest choćby w części identyczna z nazwą zabronionego głównego produktu, to również ten produkt pochodny powinien być zabroniony.

${ }^{66}$ Zezwalają na spożywanie produktów pochodnych.

${ }^{67}$ Hebr. jajin.

${ }^{68}$ Hebr. jein tapuchim - dosł. ,wino jabłkowe”. Wyraz jajin - „wino” bez żadnego dodatkowego określenia jest rozumiane jako wino $\mathrm{z}$ winogron a nie z jabłek, dlatego wino z jabłek było dozwolone temu, kto ślubował nie pić wina (jajin) z winogron.

${ }^{69}$ Hebr. szemen może oznaczać „olej”, ale też „oliwa”.

${ }^{70}$ Hebr. szemen szumszemin - „olej sezamowy” lub „oliwa sezamowa”. Wolno mu spożyć olej sezamowy, ponieważ podczas ślubowania użył terminu szemen - „olej”, który bez żadnego dodatkowego określenia jest rozumiany wyłącznie jako olej z oliwek.

${ }^{71}$ Hebr. dewasz.

${ }^{72}$ Hebr. dewasz temarim, por. poprzednią misznę. Wolno mu jeść miód daktylowy, ponieważ ślubował nie jeść „miodu” używając terminu dewasz, który bez dodatkowego określenia jest rozumiany jako „miód pszczeli”.

${ }_{73}$ Hebr. chomec.

${ }^{74}$ Wolno mu spożyć ocet winny powstały z jesiennych winogron (por. poprzednią misznę), ponieważ ślubował na wyraz chomec, który sam oznacza „skwaśniałe wino”.

${ }^{75}$ Hebr. kreszin.

${ }^{76}$ Hebr. kaflotot. Danby $(2016,273)$; Neusner (1988,. 418) i Kehati, Ned 6,9 thumacza jako „szalotki”, czyli rodzaj cebuli. Albeck (2008 III, 167) wyjaśnia, że kaflotot należały do rodziny porowatych. Szalotka w znaczeniu cebuli pojawiła się już w Szewi 2,9 pod nazwą becalim sarisim, czyli dosł. „cebule eunuchowate” oraz w Kil 1,3 jako „dzika cebula”.
} 
od warzyw ${ }^{77}$, to wolno [mu spożywać] dziko rosnące warzywa ${ }^{78}$, ponieważ to jest [tylko] to samo określenie. (Ned 6,9)

Również Ned 6,3 zajmuje się zagadnieniem popularnego rozumienia wyrazów użytych podczas ślubowania i podkreśla rolę przedimka określającego, tzw. he hajedi 'a, w powszechnym rozumieniu wyrazów. Dwie pierwsze lekcje tego rozdziału dotyczyły głównie potraw gotowanych, ta omawia inne sposoby przyrządzania pożywienia i wymienia się tu potrawy marynowane, parzone, pieczone i solone. Główny wyróżnik stanowi tu przedimek określający he hajedi 'a. Wyrazy stoją tu w opozycji: kawusz hakawusz („marynowany”), szaluk - haszaluk („,parzony”), cali - hacali („,pieczony”) i mali ach - hamali ach - ,solony”. W języku polskim trudno jest oddać tę różnicę, w pierwszym przypadku chodzi o jakieś rzeczy bliżej nieokreślone, w drugim o te określone. Terminy określone rozumiane były powszechnie jako jeden z rodzajów tych nieokreślonych:

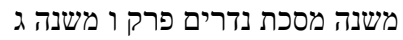

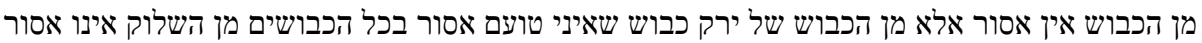

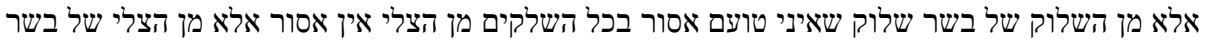

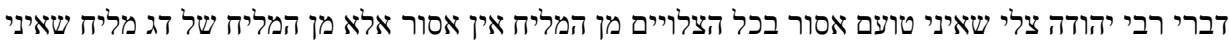
טועם אסור בכל המלוחים יהודי

Min hakawusz, ein asur ela min hakawusz szel jarak; kawusz szeeini to'em, asur bechol hakwuszim. Min haszaluk, eino asur ela min haszaluk szel basar; szaluk szeeini to 'em, asur bechol haszlakim min hacali, eino asur ela min haczli szel basar; diwrei rabi Jehuda; cali szeeino to'em, asur bechol hacluim. Min hamaliach, eino asur ela min hamaliach szel dag; Maliach szeeini to 'em, asur bechol hamluchim.

[Jeśli ślubował nie jeść niczego] marynowanego ${ }^{79}$, to nie wolno mu tylko marynowanych warzyw ${ }^{80}$. [Jeśli powiedział: „Konam], jeśli spróbuję czegoś marynowanego" $" 81$, to nie wolno [mu jeść] niczego, co jest marynowane. [Jeśli ślubował nie jeść niczego] parzonego ${ }^{82}$, to nie wolno mu tylko parzonego mięsa. [Jeśli powiedział: „Konam], jeśli spróbuję czegoś parzonego", ${ }^{\text {, }}$, to nie wolno [mu jeść] niczego parzonego. [Jeśli ślubował nie jeść niczego] pieczonego ${ }^{84}$, to nie wolno mu tylko pieczonego mięsa. To są słowa rabiego Jehudy. [Jeśli powiedział: „Konam], jeśli spróbuję czegoś pieczonego" ${ }^{" 25}$, to nie wolno mu niczego, co jest pieczone. [Jeśli

\footnotetext{
${ }^{77}$ Hebr. jarak.

${ }^{78}$ Hebr. jarkot sade - dosł. „warzywa polne”. Ślubował nie jeść warzyw z użyciem wyrazu jarak, który sam był rozumiany powszechnie jako warzywa uprawiane, a nie dziko rosnace. Gdyby to dotyczyło roku szabatowego, w którym nie uprawia się warzyw, to nie wolno byłoby mu jeść tych, które same wyrosły w polu, a dozwolone byłyby uprawiane warzywa, trudno wówczas dostępne, por. Lb 22,4; Albeck 2008 III, s. 167; Kehati, Ned 6,9.

${ }^{79}$ Hebr. hakawusz - dosł. „marynowany”.

${ }^{80}$ Ponieważ przez hakawusz rozumiano powszechnie tylko marynowane warzywa (w occie winnym).

${ }^{81}$ Hebr. kawusz bez przedimka określającego oznacza tu wszelkie potrawy marynowane.

${ }^{82}$ Hebr. haszaluk z przedimkiem określającym oznaczało powszechnie „mięso przygotowane na parze” lub „tylko podgotowane”.

${ }^{83}$ Hebr. szaluk bez przedimka określającego oznaczało powszechnie wszelkie potrawy parzone lub tylko podgotowane.

${ }^{84}$ Hebr. hacali z przedimkiem określającym oznaczało powszechnie „pieczone mięso".

${ }^{85}$ Hebr. cali bez przedimka określającego oznaczało powszechnie wszelkie potrawy pieczone.
} 
ślubował nie jeść niczego] solonego ${ }^{86}$, to nie wolno mu tylko solonej ryby. [Jeśli powiedział: „Konam], jeśli spróbuję czegoś solonego" ${ }^{\text {, }}$, to nie wolno [mu jeść] niczego solonego. (Ned 6,3)

Inne fragmenty Miszny podkreślają znaczenie zaimka wskazującego w powszechnym rozumieniu wyrazów:

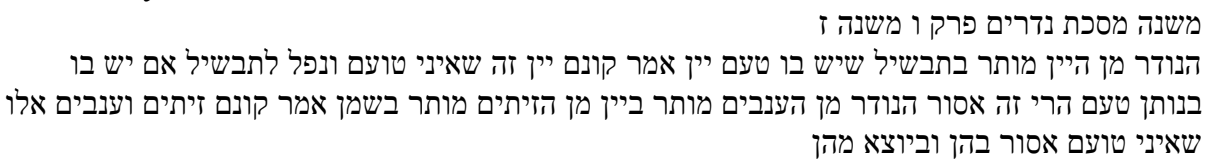

Hanoder min hajajin, mutar betawszil szejesz bo ta'am jajin. Amar: Konam jajin ze szeeini to 'em, wenafal latawszil, 'im jesz bo benoten ta'am - harei ze asur. Hanoder min ha'anawim, mutar bajajin; min hazeitim, mutar baszemen. Amar: Konam zeitim wa'anawim elu szeeini to 'em - asur bahen uwajoce mehen.

Jeśli $^{88}$ ktoś ślubował [powstrzymywać się] od wina ${ }^{89}$, to wolno mu spożywać [gotowane] potrawy, które mają smak wina. Jeżeli jednak powiedział: 'Konam, jeśli spróbuję tego ${ }^{90}$ wina', a [potem to wino] zostało dodane ${ }^{91}$ do potrawy, to gdy ma ona smak wina, jest to zabronione ${ }^{92}$. Jeśli ktoś ślubował [powstrzymywać się] od winogron $^{93}$, to wolno [mu spożywać] wino ${ }^{94}$; jeśli od oliwek ${ }^{95}$, to może spożywać oliwę [z oliwek] ${ }^{96}$. [Jeśli jednak] powiedział: „Konam, jeśli spróbuję tych oliwek ${ }^{97}$ lub winogron', to są mu zabronione [jedne i drugie i wszystko], co z nich pochodzi ${ }^{98}$. (Ned 6,7)

Podobnie do Nedarim 6,7 istotną rolę zaimka wskazującego użytego podczas ślubowania uwydatnia miszna Nedarim 7,6, gdzie mówi się, że ślubujący miał na myśli konkretny produkt, który wraz z jego pochodnymi jest mu zabroniony. Jeśli podczas

\footnotetext{
${ }^{86}$ Hebr. hamali'ach z przedimkiem określającym oznaczało powszechnie „,soloną rybę”.

${ }^{87}$ Hebr. mali'ach bez przedimka określającego oznaczało powszechnie wszelkie potrawy z użyciem soli.

${ }^{88}$ Ta miszna kontynuuje zagadnienie podjęte w poprzedniej lekcji podkreślając znaczenie zaimka wskazującego użytego w czasie ślubowania. Podobnie jak w poprzedniej misznie „mięso” tak w tej „wino” stanowi istotę ślubowania i ważne jest, czy ślubujący miał na myśli ten konkretny produkt. Jeśli tak było, a został on zmieszany w trakcie przygotowania pożywienia z czymś innym, czemu nadał smak, to cała ta mieszanka jest zabroniona.

${ }^{89} \mathrm{~W}$ formule przysięgi nie użył zaimka wskazującego $(z e)$.

90 Tutaj ślubujący zastosował zaimek wskazujący ze - „ten” („mięso” i „wino” jest w j. hebr. rodzaju męskiego).

${ }^{91}$ Hebr. wenafal-dosł. ,i wpadł”.

${ }^{92}$ To zabronione ślubem wino zostało dodane do potrawy. Jeśli zmieniło jej smak, to również ta potrawa jest zabroniona.

${ }^{93}$ Nie zaznaczył podczas ślubowania, że chodzi o te konkretne winogrona

${ }^{94}$ Jeśli wcześniej nie wskazał winogron, z których zostało sporządzone to wino.

${ }^{95}$ Nie zaznaczył podczas ślubowania, że ma na myśli te konkretne oliwki.

${ }^{96}$ Jeśli wcześniej nie zabronił sobie oliwek, z których sporządzono tę oliwę.

${ }^{97} \mathrm{Tu}$ podczas ślubowania wskazał konkretne oliwki i winogrona mówiąc zeitim waanawim elu - dosł. „te oliwki i winogrona".

${ }^{98}$ Nie wolno mu spożyć żadnej potrawy, do której sporządzenia użyto tych oliwek lub tych winogron.
} 
ślubowania nie użyto zaimka wskazującego, to zabroniony był tylko sam produkt, a jego pochodne były dozwolone (por. Ned 6,6 - 6,7):

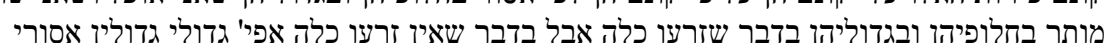

Konam perot haelu alaj, konam hen al pi, konam hen lefi - asur bechilufeihen uwgiduleihen; szeani ochel weszeani to'em, mutar bechilufeihen uwgiduleihen bedawar szezar'o kale; awal bedawar szeein zar'o kale afilu gidulei gidulin asurin.

[Jeśli ktoś powiedział:] „Konam niech będą dla mnie ${ }^{99}$ te produkty”100 albo „Niech to stanowi konam dla moich ust"101 lub „Niech to będzie konam do moich ust"102, to nie wolno mu niczego, na co mógłby je wymienić, ani tego, co z nich wyrośnie ${ }^{103}$. [Jeśli jednak powiedział: „Konam,] jeśli zjem lub jeśli spróbuję [ich] " ${ }^{, 04}$, to wolno [mu spożyć] to, na co je wymieni lub co z nich wyrośnie ${ }^{105}$. [To odnosi się] do produktu, którego nasienie uległo zepsuciu ${ }^{106}$, ale jeśli nasienie nie uległo zepsuciu ${ }^{107}$, to nie wolno mu nawet tego, co wyrośnie z tego, co już wyrosło ${ }^{108}$. (Ned 7,6)

משנה מסכת נדרים פרק ז משנה ז זמיך

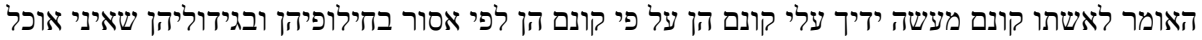

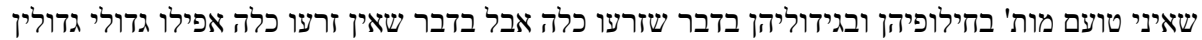

אסורים

Haomer le'iszto: Konam ma 'ase jadajich alaj, konam hen al pi, konam hen lefi-asur bechilufeihen uwgiduleihen; szeani ochel, szeani to'em, mutar bechilufeihen uwgiduleihen - bedawar szezar'o kale; awal bedawar szeein zar'o kale, afilu gidulei gidulin asurim.

Jeśli $^{109}$ ktoś $^{110}$ powiedział swojej żonie: „Konam niech będzie dla mnie ${ }^{111}$ dzieło twoich rąk” albo „Niech to stanowi konam dla moich ust”112 lub „Niech to będzie

\footnotetext{
${ }^{99}$ Hebr. alaj - dosł. „nade mną”, co wyraża powinność, zobowiązanie.

${ }^{100}$ Formuła tego ślubowania nie kończy się jak zwykle oświadczeniem ograniczającym zakaz tylko do produktu zabronionego, wypowiedzianym w trybie warunkowym, ,jeśli nie zjem” lub ,jeśli zjem”, ,jeśli nie spróbuję" lub ,jeśli spróbuję" itp., por. Ned 52b.

${ }^{101}$ Hebr. al pi.

${ }^{102}$ Hebr. lefi.

${ }^{103}$ Nie wolno mu użyć żadnego produktu, który wziąłby w zamian za ten produkt, ani też nie może przyjąć pieniędzy.

${ }^{104}$ Bez określenia ,tych”.

105 Ponieważ zabronił sobie tylko tego produktu, a jeśli będzie jadł owoce wyrosłe $\mathrm{z}$ sadzonek tego zabronionego, to będą to już inne owoce, których sobie nie zabronił. Podobnie jest $\mathrm{z}$ zamianą zabronionego produktu na inny, który nie jest zabroniony.

${ }^{106}$ Po to, żeby wydać owoc.

${ }^{107}$ Jak w przypadku cebuli, por. Ter 9,4.6; Albeck (2008 III, . 170); Kehati, Ned 7,6.

${ }^{108}$ Ponieważ zawiera nasienie zabronionego.

${ }^{109}$ Ta miszna kontynuuje zagadnienie zabronionego na mocy ślubu produktu i jego zamiany, jest bliźniaczo podobna do poprzedniej z tą różnicą, że zakaz odnosi się do dzieła rąk żony lub zapłaty za jej pracę. W formule ślubowania mąż wypowiada do żony słowa: „,konam niech będzie...” lub „,konam, jeśli...”. Tak jak w poprzedniej misznie istotną rolę odgrywa tu zaimek wskazujący użyty podczas ślubowania.
} 
konam do moich ust" ${ }^{\text {"113 }}$, to nie wolno mu niczego, na co mógłby je wymienić ${ }^{114}$, ani tego, co z nich wyrośnie ${ }^{115}$. [Jeśli jednak powiedział: „Konam, jeśli zjem” lub ,jeśli spróbuję $^{116}[\mathrm{ich}]^{1117}$, to wolno [mu spożyć] to, na co je wymieni lub co z nich wyrośnie. [To odnosi się] do produktu, którego nasienie uległo zepsuciu, ale jeśli nasienie nie uległo zepsuciu, to nie wolno mu nawet tego, co wyrośnie z tego, co już wyrosło. $^{118}$ (Ned 7,7)

Z powyższych fragmentów widać wyraźnie, że znajomość gramatyki języka hebrajskiego była czynnikiem ułatwiającym właściwe zrozumienie i poprawną interpretację tekstu zgodnie $\mathrm{z}$ jego powszechnym rozumieniem w czasach Miszny.

Niekiedy dwuznaczność terminów stanowi dodatkowe utrudnienie w zrozumieniu i właściwym przekładzie tekstu:

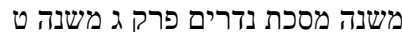

הנודר מן הילודים מותרים בנולק גולדים מן הנות מנולדים אסור בילודים רבי מאיר מתיר אף בילודים וחכמים אומרים לא נתכוין זה אלא במי שדרכו להולים

Hanoder min hajilodim, mutar banoladim; min hanoladim asur bajilodim; rabi Meir matir af bajilodim. Wachachamim omrim: Lo nitkawen ze 'ela bemi szedarko leholid. $($ Ned 3,9)

[Jeśli jednak ślubował, że nie będzie miał korzyści] z [jeszcze] „nienarodzonych”, to nie wolno mu ${ }^{119}$ mieć korzyści z [już] „narodzonych"120.

Im bardziej język źródłowy różni się od docelowego, tym trudniejsze może okazać się zrozumienie dosłownego tłumaczenia bez zmian w samych słowach lub ich kolejności. Tej dosłowności odnoszącej się do szyku wyrazów w zdaniu nie można w żadnym wypadku zachować w przekładzie na język polski, gdyż język hebrajski klasyczny ma ustalony porządek: orzeczenie, podmiot, dopełnienie bliższe, dopełnienie dalsze, a okolicznik na początku lub na końcu zdania. ${ }^{121}$

\footnotetext{
${ }^{110}$ Mąż.

${ }^{111}$ Hebr. alaj, por. poprzednią misznę.

${ }^{112}$ Hebr. al pi, por. poprzednią misznę.

${ }^{113}$ Hebr. lefi, por. poprzednia misznę.

${ }^{114}$ Skoro zabronił sobie tego, co zrobi lub przygotuje jego żona, to nie wolno mu również mieć korzyści z zamiany tych produktów na inne.

${ }^{115} \mathrm{~Np}$. tego co wyrośnie z zamienionych produktów lub tych roślin, które żona zasiała lub posadziła.

${ }^{116} \mathrm{~W}$ formule ślubowania dodał ,jeśli zjem” lub ,jeśli spróbuję", co ograniczyło jego ślub tylko do produktów przygotowanych przez żonę, dlatego może korzystać z produktów zamienionych lub tego, co wyrośnie z produktów mu zabronionych. Jeśli będzie jadł produkty wyrosłe z sadzonek zabronionych, to nie będą to już produkty jemu zabronione, por. poprzednią misznę.

${ }^{117}$ Nie użyto tu zaimka wskazującego, produkty pochodne są dozowlone.

118 To ostatnie zdanie wystąpiło już w poprzedniej misznie i tam zostało wyjaśnione.

${ }^{119}$ Niektóre teksty Miszny opuszczają to zdanie, por. Danby $(2016,67)$.

${ }^{120}$ Ponieważ termin noladim może oznaczać zarówno „nienarodzonych” jak i ,narodzonych”.

${ }^{121}$ Miałoby to sens jedynie dla czytelnika znającego język hebrajski, gdyż ekwiwalencja formalna może mu pozwolić na przeanalizowanie sposobu wyrażenia myśli w oryginalnym tekście. Zachowuje ona nieprzetłumaczone idiomy, figury retoryczne oraz wybór słów, pozostawiając w jak najmniej zmienionym stanie oryginalne informacje i podkreślając delikatniejsze odcienie znaczeniowe.
} 
W tłumaczeniu niektórych wyrażeń hebrajskich zastosowałem przekład wolny, np. występujący kilkanaście razy w traktacie Miszny Gitin (Listy rozwodowe), szczególnie w rozdziale czwartym i częściowo piątym, zwrot mipne tikun olam lub mipne tikun haolam - dosł. „z powodu naprawy świata” tłumaczę jako „dla dobra ogółu”. Żeby to zilustrować, zamieszczam poniżej niewielki fragment przekładu z podkreśleniem wspomnianego wyżej zwrotu:

Nie wykupuje się uprowadzonych do niewoli za większą [sumę] od ich wartości ${ }^{122}$, dla dobra ogółu, jak też nie pomaga się im w ucieczce, dla dobra ogółu. Rabban Szimon ben Gamliel mówi: Dla dobra uprowadzonych. Nie nabywa się [też] zwojów, tefilin i mezuz od gojów za więcej niż są warte ${ }^{123}$, dla dobra ogółu. (Git 4,6)

Dla lepszego zrozumienia trudności związanych z przekładem Miszny posłużę się konkretnym przykładem zamieszczając poniżej jedną lekcję z traktatu Nazir 4,5 najpierw w oryginale hebrajskim, następnie w dosłownym tłumaczeniu i ostatecznie we właściwym przekładzie z komentarzem.

Tekst oryginalny:

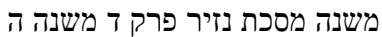

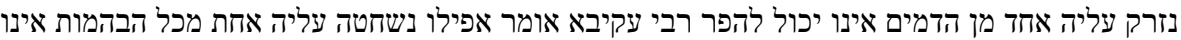

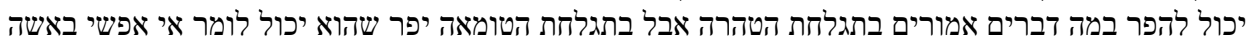

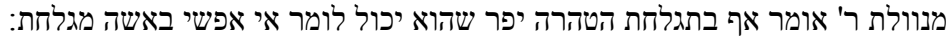

Nizrak aleiha echad min hadamim - eino jachol lehafer. Rabi Akiwa omer: Afilu niszchata aleiha achat mikol habehemot - eino jachol lehafer. Bame dewarim amurim? Betiglachat hatohora. Awal betiglachat hatum'a - jafer, szehu jachol lomar: I efszi beisza menuwelet. Rabi omer: Af betiglachat hatohora - jafer, szehu jachol lomar: I efszi be 'isza megulachat. (Naz 4,5)

Dosłowne thumaczenie fragmentu Miszny z traktatu Nazir 4,5:

Została skropiona nad nią jedna z krwi - nie może odwołać. Rabi Akiwa mówi: Nawet zostało zarżnięte nad nią jedno z jej zwierząt, nie może odwołać. O czym mówią te słowa? O ogoleniu czystości. Ale przy ogoleniu nieczystości odwoła, ponieważ może powiedzieć: „Nie chcę tej plugawej kobiety!” Rabi mówi: Nawet przy ogoleniu czystości odwoła, ponieważ może powiedzieć: „Nie chcę tej ostrzyżonej kobiety!".

Poniżej zamieszczam ten sam fragment Miszny z traktatu Nazir 4,5 w przekładzie uwzględniającym całe tło religijno-kulturowe wraz z komentarzem:

Jeśli $^{124}$ został już skropiony [ołtarz] krwią z jednej z [jej ${ }^{125}$ ofiar], ${ }^{126}$ to [jej mąż] nie może odwołać [jej ślubu]. ${ }^{127}$ Rabi Akiwa mówi: Nawet jeśli [tylko] jedno $\mathrm{z}$ jej

\footnotetext{
${ }^{122}$ Żeby pojmanie do niewoli nie stało się intratnym zajęciem, por. Danby $(2016,311)$

${ }^{123}$ Aby nie stało się to intratnym zajęciem, por. Albeck $(2008,293)$.

${ }^{124}$ Ta miszna rozważa możliwość odwołania przez męża nazireatu jego żony.

${ }^{125}$ Hebr. aleiha - dosł. „nad nią”, ale też ,z jej powodu”.

${ }^{126}$ Hebr. damim to 1 . mnoga od wyrazu dam - „krew”. Tutaj chodzi o krew ofiar.
} 
zwierząt [przeznaczonych na ofiarę] zostało zarżnięte, ${ }^{128}$ to [mąż] nie może odwołać [jej ślubu]. ${ }^{129}$ Czego dotyczą te słowa? Dotyczą ofiary składanej po wypełnieniu nazireatu $\mathrm{w}$ czystości. ${ }^{130}$ Jeśli jednak ofiara nie została jeszcze złożona, a ślub nie był wypełniony w czystości ${ }^{131}$ i wymaga wypełnienia jeszcze raz od nowa, to [mąż] może [go] odwołać, gdyż może powiedzieć „Nie chcę tej plugawej kobiety”. ${ }^{132}$ Rabi mówi: Także w [sytuacji, gdy] ofiara została złożona po wypełnieniu nazireatu w czystości ${ }^{133}$ [mąż] może odwołać [jej ślub], ${ }^{134}$ gdyż może powiedzieć „Nie chcę [więcej] takiej ostrzyżonej kobiety". ${ }^{135}$ (Naz 4,5)

Powyższy przykład dobitnie wykazał konieczność uprzedniej znajomości tła religijno-kulturowego, bez czego nie da się rozwiązać skrótów myślowych, dotrzeć do sedna judaizmu w celu właściwego zrozumienia tekstu Miszny. Dopiero po spełnieniu tych warunków można zająć się jej przekładem i to przekładem komentowanym, gdyż wielu fragmentów Miszny nie da się zrozumieć w ich dosłownym tłumaczeniu, ale dopiero wraz z odpowiednim komentarzem. Dlatego, o czym już wyżej wspomniano, poza jednym wyjątkiem ${ }^{136}$, przekłady Miszny są przekładami komentowanymi.

Język Miszny jest przede wszystkim językiem halachy wyrażającym przepisy religijne, nakazy, zakazy, wyjaśnienia, pouczenia, praktyczne wskazówki co do zasad postępowania w różnych okolicznościach. Dla lepszego zrozumienia tekstu konieczne było niekiedy dodanie jakiegoś wyrazu w polskim przekładzie. Wszystkie tego rodzaju dodatki $\mathrm{w}$ tekście podano $\mathrm{w}$ nawiasach kwadratowych. Wielokrotnie trzeba było też

\footnotetext{
${ }^{127}$ Nawet jeśli ona się jeszcze nie ostrzygła i nie przyniosła pozostałych ofiar nazirejskich, jej mąż nie może już odwołać jej ślubu odkąd rozpryskano krew jednej z jej ofiar, co zwalnia ją z obowiązków nazireatu, por. Naz 6,9 .

${ }^{128}$ I jeszcze nie rozpryskano jego krwi.

${ }^{129}$ Gemara wyjaśnia, że odwołanie nazireatu w tym momencie sprawiłoby zmarnowanie ofiar nazirejskich.

${ }^{130}$ Hebr. tiglachat hatohora - dosł. „ogolenie czystości” lub „ostrzyżenie czystości”. Chodzi tu o ostrzyżenie włosów i złożenie ofiar nazirejskich po wypełnieniu ślubu nazireatu w czystości. W omawianym w tej misznie przypadku kobieta wypełniła swój ślub nazireatu i w dniu, w którym się ostrzygła, złożyła swoje ofiary nazirejskie przewidziane zgodnie $\mathrm{z}$ prawem dla nazireatu wypełnionego w czystości. Jedno z jej zwierząt ofiarnych zostało już zarżnięte w jej imieniu (jak twierdzi rabi Akiwa) lub na jej polecenie krew z jednej z ofiar została rozpryskana na ołtarzu (zgodnie z Pierwszym Tannaitą). Ponieważ wypełniła już ślub nazireatu i była zobowiązana jeszcze tylko, żeby się ostrzyc, to wolno jej już było pić wino i nie obowiązywały jej już zakazy nazireatu, dlatego mąż nie mógł odwołać ślubu, który już nie obowiązywał.

${ }^{131}$ Hebr. tiglachat hatum 'a - dosł. „ostrzyżenie nieczystości”. W omawianym tu przypadku kobieta podczas nazireatu skalała się nieczystością zmarłego, dlatego powinna zgodnie z Torą ostrzyc głowę w dniu jej oczyszczenia, czyli siódmego dnia, a ósmego przynieść w ofierze dwie synogarlice lub dwa gołębie, które kapłan złoży w jej imieniu jako ofiarę przebłagalną za grzech oraz jako ofiarę całopalną, por. Lb 6,9-11; Naz 6,6-7.

${ }^{132}$ Która się skalała nieczystością zmarłego lub jako nazirejka piła wino przecząc samej sobie.

${ }^{133}$ Hebr. tiglachat hatohora wyjaśniono wyżej.

${ }^{134}$ Nawet po spryskaniu ołtarza krwią jednej z jej ofiar po wypełnieniu ślubu nazireatu w czystości mąż zdaniem rabiego Jehudy - może jeszcze odwołać jej ślub, zanim ona nie ostrzyże swoich włosów, por. Albeck, tamże; Kehati, tamże.

${ }^{135}$ Rabi Jehuda wskazuje, że ostrzyżona kobieta jest odrażająca i podaje to jako przyczynę oddalenia jej przez męża. Gemara wyjaśnia, że Pierwszy Tannaita nie widzi tego problemu, ponieważ kobieta może założyć perukę. Rabi Jehuda zaś uważa, że peruka żony może drażnić męża, por. Kehati, tamże.

${ }^{136}$ Jacob Neusner (1988) przetłumaczył Misznę bez oddzielnego komentarza, który jednak po części wpisał w tekst przekładu dla jego zrozumienia.
} 
zamieścić $\mathrm{w}$ tekście oryginalne hebrajskie nazewnictwo. Zastosowano w tym celu maksymalnie uproszczoną polską transliterację (Marcinkowski 2013, 14-15).

Czytając Misznę można często odnieść wrażenie wyjątkowego przywiązania do szczegółów, a nawet „jałowej” dysputy wpasowanej w katalog praw (Danby 2016, s. xxvi). Towarzyszy temu ciągła różnorodność opinii, zwykle przeciwstawnych, tego czy innego mędrca, czasami opartych bezpośrednio na fragmentach Tory lub wynikających z logicznego myślenia, innym razem wskazujących precedens - odnoszące się do tematu wydarzenie z przeszłości lub wyimek z nauczania starszych pokoleń. Misznę cechują suche, zwięzłe opinie wyrażające postanowienia halachiczne, niekiedy tylko przeradzające się w tekst narracyjny, a jeszcze rzadziej przyjmujące agadyczną formę opisu, która charakteryzuje Gemarę. Misznaickie opinie są często zredukowane tylko do najważniejszych terminów - słów kluczowych, co można by nazwać minimalizacją formy przekazu przy zachowaniu maksymalizacji treści. Ten schemat, na co już wcześniej wskazano, służył kiedyś lepszemu zapamiętywaniu ustnego przekazu. Taką formę wypowiedzi trudno jest zrozumieć współczesnemu odbiorcy Miszny bez uprzedniego dokładnego zgłębienia tematu, zaznajomienia się z całym wspomnianym wyżej tłem religijno-kulturowym.

Dlatego każdy przekład tekstu Miszny jest znacznie dłuższy od oryginału ${ }^{137}$. Przyczyną tego jest charakterystyczna dla języka Miszny (jak i w ogóle dla języków starożytnych) zwięzłość wypowiedzi. W języku Miszny dodatkową zwięzłość powodują przyjęte wcześniej schematy ustnego przekazu. Różnorodność wypowiedzi cechująca styl Miszny jest naturalnym następstwem wielości źródeł, z których czerpał główny jej kodyfikator Jehuda Hanasi.

Język Miszny nie jest zwykłym językiem, zawierającym proste sformułowania przedstawiające zwyczajne rzeczy, a raczej należałoby go postrzegać jako specyficzną odmianę naturalnej w owych czasach hebrajszczyzny, służącą wyłącznie do przekazu najistotniejszych treści religijnych. Język tannaitów w sferze gramatyki i słownictwa określił na wiele wieków kształt języka religijnego judaizmu, czego wyraźne ślady widać głównie w późniejszych zbiorach modlitw (sidurach), a także w średniowiecznej literaturze, zwłaszcza poezji religijnej $($ pijut $) .{ }^{138}$

Często jednak trudno byłoby ustalić wyraźną granicę między ekwiwalencją dynamiczną i formalną, gdyż obie pozwalają na podchodzenie do tłumaczenia na wiele sposobów. Dlatego też w zależności od potrzeby i kontekstu można było użyć każdego z rodzajów ekwiwalencji w różnych miejscach tego samego tekstu. Co więcej, w niektórych przypadkach thumaczenie może być zarówno dynamiczne, jak i formalnie ekwiwalentne $\mathrm{z}$ tekstem oryginalnym.

${ }^{137}$ W tekście Miszny można znaleźć bardziej zwięzłe (od przedstawionego wyżej przykładu z traktatu Nazir 4,5) formy wypowiedzi, np. fragment traktatu Miszny Arachin 4,1, a dokładniej mówiąc zdanie rozpoczynające tę lekcję, zawierające tylko 10 wyrazów hebrajskich, zostało przetłumaczone przez H. Danby'ego na język angielski przy pomocy 82 wyrazów, a przez J. Neusnera przy pomocy 87 wyrazów angielskich, por. Danby, (2016, 546); J. Neusner, (1988, 813-814).

${ }^{138}$ Wskazuje na to wielu badaczy, np. Chanoch Yalon, Mawo lenikud ha-Miszna (Wprowadzenie do wokalizacji Miszny), Jeruszalaim 724 (Jerozolima 1964), s. 152-159, Ilan Eldar, Mesorot hakri'a hakedem-aszkenazit, mahut wehajesodot hameszutafim la ulemesorot sfarad (Przedaszkenazyjskie tradycje czytania, ich istota $i$ wspólne podstawy z tradycjami sefardyjskimi), tom 2, Jeruszalaim 739 (Jerozolima 1979), s. 180, 184nn., 381383, czy Joseph Yahalom, Sfat haszir szel hapijut haerec-isreeli hakadom (Język dawnej poezji religijnej), Jeruszalaim 745 (Jerozolima 1985), s. 162-176. 
Starałem się w przekładzie Miszny na język polski stosować ekwiwalencję formalną, kładąc nacisk na ścisłość i poprawność, zachowanie aspektów formalnych języka źródłowego przez m.in. tłumaczenie zdania zdaniem i wyrażanie w języku docelowym treści informacji tak, aby były one możliwie jak najbliższe treściom informacji wyrażonych w języku wyjściowym. To z kolei, zgodnie ze wspomnianą wyżej teorią przekładu, wiązało się z koniecznością zamieszczania przypisów (gloss translation), pozwalających czytelnikowi przekładu ,wczuć się” w rolę czytelnika oryginału i poznać jego „zwyczaje, tok rozumowania i sposób wyrażania myśli” (Nida 1964, s. 159). Dokładniej mówiąc, w moim przekładzie Miszny ekwiwalencja formalna jest często jedynie celem, w którego kierunku zmierza tłumaczenie.

Mam nadzieję, że udało mi się przedstawić odpowiednie przykłady ekwiwalencji w tłumaczeniu Miszny i wskazać złożoność spraw związanych z jej pierwszym przekładem na język polski. W podsumowaniu chciałbym jeszcze raz wyraźnie podkreślić, że tłumaczenie tekstów religijnych judaizmu nie ogranicza się tylko do przekładu, ale wymaga znacznie szerszej wiedzy wykraczającej poza znajomość języka i warsztat filologa.

\section{REFERENCES}

Albeck, Chanoch. 2008. חנוך אלבק, ששה סדרי משנה, ירושלים-תל-אביב תשס"ח Jerusalem - Tel Aviv: The Bialik Institute - Dvir Publishing House.

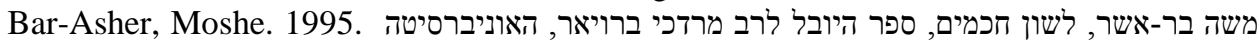
32-1 העברית, ירושלים, התשנ"ה, עמ' Jerusalem: Academon.

Catford, John. C. 1965. A Linguistic Theory of Translation. Oxford: Oxford University Press.

Danby, Herbert. 2016. The Mishnah: Translated from Hebrew with Introduction and Brief Explanatory Notes. Peabody, MA: Hendrickson.

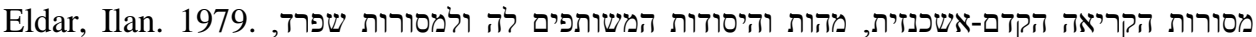

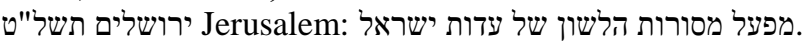

Kehati, Pinhas. 1994. The Mishnah: A New Translation With a Commentary, Translated by Rafael Fisch. Jerusalem: Department for Torah Education and Culture in the Diaspora of the World Zionist Organization.

Kehati, Pinhas. 2003. משניות מבוארות. Jeruszalajim (Jerozolima): הוצאת משניות קהתי בע"מ.

Körner, Jutta. 1986. Hebräische Studiengrammatik. Leipzig: VEB Verlag Enzyklopädie.

Marcinkowski, Roman. 2004. Paradygmaty religijności $w$ judaizmie rabinicznym. Miszna $i$ inne teksty talmudyczne o szabacie, święcie, pótświęcie i powszedniości. Kraków: Antykwa.

Marcinkowski, Roman, ed. 2013. Miszna: Zeraim (Nasiona). Warszawa: Wydawnictwo DiG.

Marcinkowski, Roman, ed. 2014. Miszna: Moed (Święto). Warszawa: Wydawnictwo DiG.

Marcinkowski, Roman, ed. 2016. Miszna: Naszim (Kobiety). Warszawa-Bellerive-sur Allier: Wydawnictwo DiG - Edition La Rama.

Neusner, Jacob. 1988. The Mishnah: A New Translation. New Haven and London: Yale University Press. 
Nida, Eugene. A. 1961. Bible Translating: An Analysis of Principles and Procedures with Special Reference to Aboriginal Languages (1947; rev. 1961). New York: American Bible Society.

Nida, Eugene. A. 1964. Towards a Science of Translating. Leiden: E. J. Brill.

Nowicki, Paweł. 1978. Hebrajszczyzna biblijna. Warszawa: Akademia Teologii Katolickiej.

Piotrowska, Maria. 2008. Czy znajomość strategii jest $w$ warsztacie każdego ttumacza niezbędna? (O strategii teoretycznie). Przekładaniec 17:217-230.

Price, James. D. 2007. A Theory for Bible Translation: An optimal Equivalence Model. New York: The Edwin Mellen Press.

Simon, Heinrich. 1977. Lehrbuch der modernen hebräischen Sprache. Lepzig: VEB Verlag Enzyklopädie.

Steuernagel, Carl. 1962. Hebräische Grammatik. Lepzig: VEB Verlag Enzyklopädie.

Tyloch, Witold. 1985. Gramatyka języka hebrajskiego. Warszawa: Wydawnictwa Uniwersytetu Warszawskiego.

Vinay, Jean-Paul, and Jean Darbelnet. 1958/2000. “A Methodology for Translation.” In The Translation Studies Reader, edited by Lawrence Venuti, 84-93. London: Routledge.

Vinay, Jean-Paul, and Jean Darbelnet. 1995. Comparative Stylistics of French and English: A Methodology for Translation. Amsterdam: John Benjamins.

Waliński, Jacek. T. 2015. "Translation Procedures". In Ways to Translation, edited by Łukasz Bogucki, Stanisław Goźdź-Roszkowski, and Piotr Stalmaszczyk, 55-67. Łódź: Łódź University Press. Available at https://www.researchgate.net/publication/ 282504599_Translation_Procedures.

Yahalom, Joseph. 1985. שפת השיר של הפיוט הארץ-ישראלי הקדום, ירושלים תשמ"ה Jerusalem: Magnes Press.

Yalon, Chanoch. 1964. מבוא לניקוד המשנה, ירושלים תשכ"ד Jerusalem: The Bialik Institute.

This work is licensed under the Creative Commons Attribution 3.0 Unported License.

http://creativecommons.org/licenses/by/3.0/

AUTHOR'S BIO: Roman Marcinkowski, Associate Professor at the Neophilological Department of the University of Warsaw. He is philologist and religious studies expert, author of many publications from the area of Hebrew and Judaistic Studies, including international publications in Hebrew. On top of that, he is a translator and editor of the first Polish printing of Mishnah. He has realized five grants from the State Committee for Scientific Research (Komitet Badań Naukowych). Among many other books, he published Paradigms of Religiousness in Rabbinic Judaism (2004), and The Mishnah: Nashim (Women) (2016).

E-MAIL: r.marcinkowski@uw.edu.pl 